\title{
中耳真珠腫の対側耳の観察
}

\author{
中村一佐藤 宏昭・本庄临
}

\section{Clinical Examination of the Contralateral Ear in Patients with Cholesteatoma}

\author{
Hajime Nakamura, Hiroaki Sato and Iwao Honjo \\ (Kyoto University)
}

To clarify whether or not a common pathogenic factor exists between the affected and contralateral ear in patients with cholesteatoma, we performed the measurement mastoid pneumatization and a inflation-deflation test in 92 contralateral ears.

About $70 \%$ of the contralateral ears showed abnormal findings of the ear drum. The majority of the contralateral ears showed poor pneumatization. Therefore, we considered these cases to reflect impaired tubal function in childhood. The conditions of the contralateral ears were similar to those of the affected ears, suggesting a common pathogenic factor in this disorder.

Key words : cholesteatoma, contralateral ear, tubal function, mastoid pneumatization

はじめに

中耳の慢性疾患はしばしば両側の耳に発症す ることが知られている1 ${ }^{1}$ ，真珠腫についても両 側罹患例の報告2) が見られるが，対側耳につい ての耳管機能を含めた総合的な報告は従来乏し い. 我々は，真珠腫の対側耳に高頻度に鼓膜の 異常所見が認められることに着目し，対側耳の 所見と真珠腫側との関係につきすでに報告3)4) しているが，今回更に観察の対象と観察の項目 とをふやし，中耳真珠腫の成因にかかわる耳管 機能の意義を知ろうとした。

\section{観察の対象}

中耳真珠腫新鮮例のうち耳管機能を測定しえ た 107 耳を観察の対象とした. 年齢分布は 5 歳 から75歳であり，男性56耳，女性51耳である。 真珠腫は鼓膜所見により，1）鼓膜弛緩部また
は後上象限に陥凹が存在し，ここに真珠腫塊を 認めた陷凹型，2）鼓膜穿孔縁より上皮が鼓室 内に侵入し，乙こに真珠腫の形成を認めた穿孔 型，3）鼓膜に異常を認めず，手術により初め て真珠腫を確認した先天型の 3 つに分類した.

\section{観察の方法}

1. 対側耳の鼓膜所見

顕微鏡による対側耳鼓膜の観察を行い，正常 鼓膜, 鼓膜穿孔, 鼓膜弛緩部の陥凹, 真珠腫, その他（滲出性中耳炎, 癒着性中耳炎等）に分 類した。

\section{2. 対側耳の耳管機能}

対側耳の鼓膜穿孔あるいは鼓膜切開孔よりの 圧負荷 (inflation-deflation test) により耳管の 陽圧および陰圧平衡能の有無を測定した.なお， 今回は陰圧平衡能の結果のみを観察の項目と 
し，中耳に負荷した $-200 \mathrm{mmH}_{2} \mathrm{O}$ の陰圧を嚥 下で少しでも解除出来た場合を耳管の動的換気 能良好，解除を認めない例を不良と判定した ${ }^{6}$.

3. 対側耳の乳突蜂巣発育

耳レ線（シューラー法）にデジタイザー (planix 5000，TAMAYA）を用いて面積計測を 行なった．対照として聴力，鼓膜ともに正常な 56 耳の乳突蜂巣面積を測定して，得た值（平均 $13.8 \mathrm{~cm}^{2}$, 標準偏差 $\left.5.6 \mathrm{~cm}^{2}\right)$ より, $8.2 \mathrm{~cm}^{2}$ (mean-1SD) 以上を発育正常， $8.2 \mathrm{~cm}^{2}$ 未満を 発育不良と判定した7).

\section{結 果}

1. 対側耳の鼓膜所見

真珠腫の対側耳鼓膜になんらかの異常所見を 認めたあのは107耳中70\%（75耳）の高率であり， うち弛緩部の陥凹 $30 \%$ （8耳），鼓膜穿孔 $9 \%$ (10耳), 真珠腫 $7 \%$ ( 8 耳)，その他の異常 $15 \%$ (16耳)，であった。一方，先天型真珠腫例では 対側耳の鼓膜は全例正常であった(図 1).

2. 対側耳の鼓膜所見と耳管機能との関係 対側耳の鼓膜所見を正常群と異常群とに分

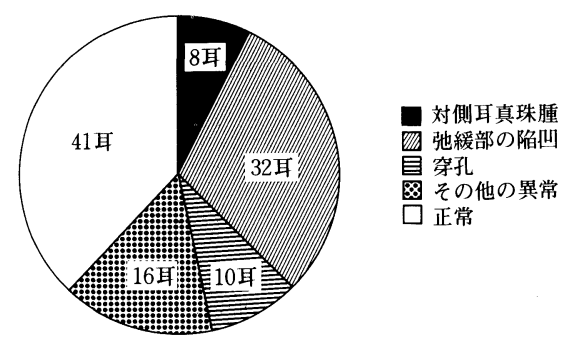

図1

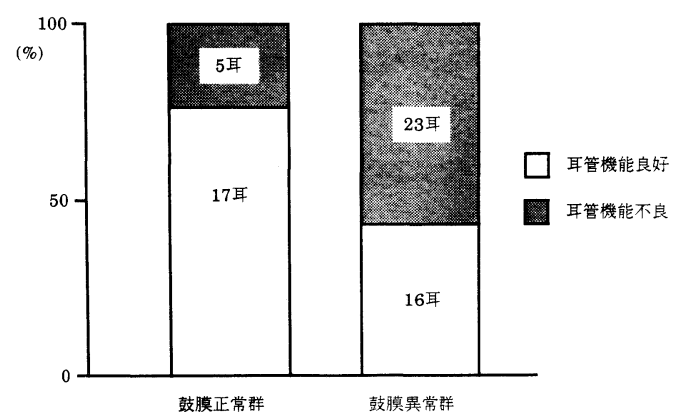

図 2
け，その各々につき耳管機能の測定結果を見る と，鼓膜正常群(22耳)では，耳管の動的換気能 が良好であった例が77\% (17耳) と高い率を占め たが，逆に鼓膜異常群(39耳)では耳管機能が良 好であったものは $41 \%(16 耳)$ と半数にみたない ことがわかった（図 2 ).

3. 対側耳の鼓膜所見と蜂巣発育との関係 鼓膜が正常な群(35耳)では乳突蜂巣の発育が 正常であるものが $80 \%$ (28耳) と高率に認められ た. そのうち先天性真珠腫 (6耳)ではその $83 \%$ ( 5 耳) で対側耳の蜂巣発育は正常であった。逆 に，鼓膜異常群(24耳)では67\%(16耳) と過半数 で蜂巣の発育が抑制されていることがわかった (図 3).

4. 対側耳の鼓膜所見と真珠腫のタイプ

対側耳の鼓膜所見と真珠腫側のタイプとの関 連をみたところ対側耳鼓膜の弛緩部に陥凹を呈 する例(32耳)では患側耳の真珠腫は91\%(29耳) で陥凹型の真珠腫であった。一方，対側耳鼓膜 が鼓膜穿孔を呈する例(10耳)では70\% (7 耳)で 患側耳の真珠腫は穿孔型の真珠腫であった。 こ のように対側耳と真珠腫側の患耳との鼓膜所見 に基づく病型の一致度が高いととがわかった (Fischer の直接確率計算法により $1 \%$ 以下の危 険率）（表 1 ).

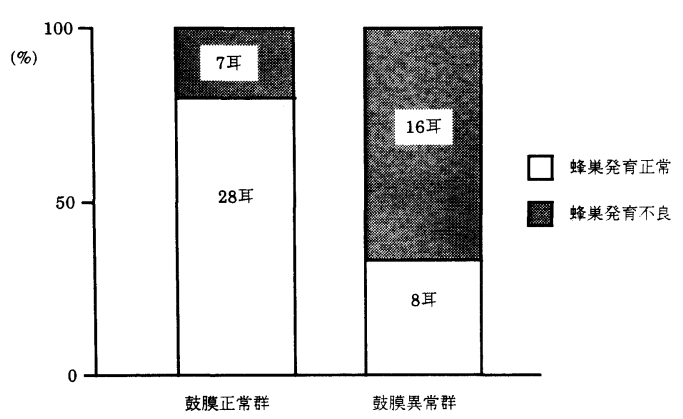

図 3

表 1

\begin{tabular}{c||c|c}
\hline \hline 対側耳の病変 & 陥凹型真珠腫 & 穿孔型真珠腫 \\
\hline 弛緩部の宿凹 & $29 耳$ & 3 耳 \\
鼓 膜 穿 孔 & 3 耳 & 7 耳
\end{tabular}




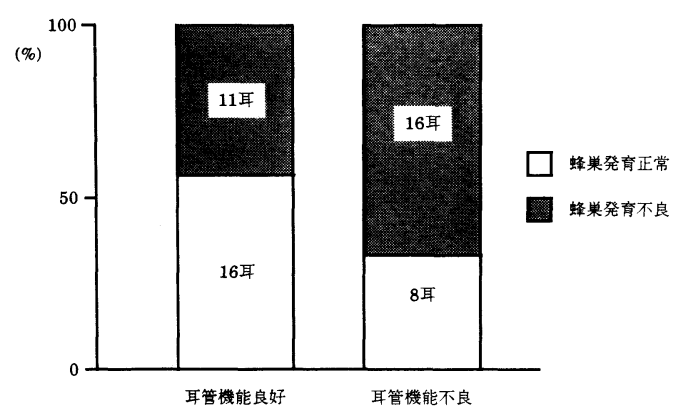

図 4

5. 対側耳の耳管機能と蜂巣発育との関係 対側耳の耳管機能を良好群と不良群とに分 け, 各々の乳突蜂巣の発育を見たところ, 対側 耳の耳管機能良好群 (27耳) では60\%(16耳)で乳 突蜂巣の発育が正常であった。 これに対して, 耳管機能不良群 (24耳)では蜂巣発育正常例は33 $\%$ (8耳)にとどまり, 対側耳の耳管機能と蜂巣 発育との間に関連性があるととがわかった（困 $4)$.

\section{考按}

中耳真珠腫の成因や病態については諸説9 10) があり，完全に解明されたとは言い難い。しか し, 滲出性中耳炎等の幼小児期の中耳病変が後 天性真珠腫の発症に関わっている可能性は指

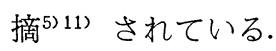

耳管の換気能障害が真珠腫成因の 1 つと考え られているが, 我々はすでに, 後天性真珠腫で は患側耳の蜂巣発育が高率に抑制されているこ とを報告377 し，真珠腫の患側では小児期に耳 管障害が存在した可能性が高いととを示した。 また， 口蓋裂を伴う滲出性中耳炎例では健側に あ耳管障害が認められる報告 ${ }^{21}$ があり，患側耳 に耳管障害をもたらしたと同一の病因が対側耳 にも影響を及ぼす可能性が考えられている8. 今回中耳真珠腫例の対側耳に焦点をしぼって耳 管機能を中心に観察を行なったのは，真珠腫発

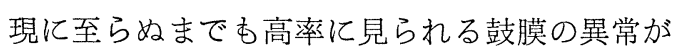
果たして耳管障害によるあのか否かを知ろうと したからである。

その結果，対側耳に扔いて鼓膜に異常を呈す
る群ではその半数に耳管障害が認められたとと は真珠腫形成の基盤としての耳管障害を示唆す るむのといえる。

また対側耳の耳管障害が，観察が行なわれた 時点で存在するのか，または小児期から存在し たのかを知るために，乳突蜂巣発育を検討した 結果でも, 対側耳の鼓膜異常群では乳突蜂巣発 育は著明に抑制されており，対側耳においても 小児期になんらかの耳管障害が存在していたと 推測された.さらに，対側耳の異常鼓膜所見と 真珠腫側耳の所見が極めて類似していることか ら, 同一の病因が真珠腫と対側耳の異常とを引 き起としたと考えるのが妥当と思われた. この ことは, 真珠腫側のみでなく, 対側耳を含めて 真珠腫の病態を捉えるべきととを示すものとい える。

以上の観察結果から幼小児期の耳管機能障害 の存在, あるいはその治癒が遷延化して現在に 至るあ耳管障害があることが中耳真珠腫の発症 の 1 つの要因になりうることが示されたが，左 右の耳管障害の条件は近似していると考元られ るにあかかわらず，一側耳は真珠腫となり対側 耳は真珠腫の発症に至らないととは, 耳管障害 の因子に加え，むう 1 つないしは 2 つの付加因 子が真珠腫の発症には必要であるととを示すす のといえる.

いずれにせよ, 真珠腫の対側耳の病態は患側 と極めて類似しており，乙れらの観察をつみ重 ねていくことで, 真珠腫成因の解明の手がかり が得られるあのと考えられる.

\section{まとめ}

1. 真珠腫の対側耳鼓膜には異常所見が高率 に認められた。

2. 対側耳の多くは乳突蜂巣の発育が不良で あり，小児期になんらかの病変が存在したと考 えられた。

3. 対側耳の病態は患側に類似の病変が見ら れ, 両耳に共通した病因の存在が示唆された。

な抢，本論文の要旨は第39回日耳鼻京滋合同地方 部会（1987）および Cholesteatoma and Mastoid 
Surgery: third international conference (copenhagen, 1987）にてロ演した.

\section{文 献}

1）立木 孝, 村井国男, 村井盛子 : 慢性中耳炎の両 耳性について. 耳鼻 $15: 143 \sim 147,1969$.

2 ) 山本悦生, 広野喜信, 内藤 泰 : 中耳真珠腫の両 側性. 臨床耳科 $14: 258 \sim 259,1987$.

3) Honjo I, Nakamura H, Naito Y, et al : Eustachian tube function in patients with cholesteatoma. Third International Conference on Cholesteatoma and Mastoid Surgery. Kugler \& Ghedini Publications, Amstelveen (in press).

4) Nakamura H, Sato H, Honjo I, et al : Cholesteatoma in view of the contralateral ear. Third International Conference on Cholesteatoma and Mastoid Surgery. Kugler \& Ghedini Publications, Amstelveen (in press).

5 ) Bluestone CD, Cantekin EI, Beery QC, et al : Function of the eustachian tube related to surgical management of acquired aural cholesteatoma in children. Laryngoscope $88: 1155 \sim$ 1163, 1978.

6 ）林 正彦, 佐藤宏昭, 広野喜信, 他 : 耳真珠腫の 耳管機能. 耳鼻臨床 $80: 559 \sim 563 ， 1987$.
7 ) 中村 一, 佐藤宏昭, 本庄 嚴 : 真珠腫の乳突蜂 巣発育. 臨床耳科 $15: 238 \sim 239,1987$.

8) Jacker RK and Shcindler RA: Role of the mastoid in tympanic membrane reconstruction. Laryngoscope $94:$ 495 500, 1984.

9) Sade J, Babyatzki A and Pinkus G : The metaplastic and congenital origin of cholesteatoma. Cholesteatoma and mastoid surgery. pp 305 319, Kugler Publications, 1981.

10) Portmann $M:$ The "invagination theory" for the pathogenesis of cholesteatoma. Cholesteatoma and mastoid surgery. pp 265 266, Kugler Publications, 1981.

11）佐藤弥生：真珠腫性中耳炎の㧕制型乳突蜂栄につ いて一対側耳からの検討一. 日耳鼻 $91: 1933 \sim$ 1937, 1988.

12）田坂康之, 倉田響介, 川野通夫, 他 : 耳管加ら見 た口蓋裂例の中耳疾患. 耳鼻臨床 $80: 571 \sim 577$, 1987.

$\left(\begin{array}{l}\text { 原稿採択 : 平成元年 } 3 \text { 月 } 22 \text { 日 急載 } \\ \text { 別刷請求先 : 中村 - } \\ \text { †606 京都市左京区聖護院川原町54 } \\ \text { 京都大学医学部耳鼻咽喉科学教室 }\end{array}\right)$ 